Uşak Üniversitesi Sosyal Bilimler Dergisi

$2013,6 / 4$

E. KILINÇ

\title{
Sosyal Bilgiler Öğretmen Eğitiminde Güncel Tartışmalar
}

Emin KILINÇ*

\section{Özet}

Sosyal bilgiler dersinin temel amacı, demokratik bir ülkede vatandaşlık vazifesini yerine getirebilmek için, öğrencilerin sahip olması gereken bilgi, beceri ve davranışlardan meydana gelen vatandaşlik yeterliliklerini arttırıp; onları etkin birer yurttaş ve birey olarak yetiştirmektir. Bu nedenle sosyal bilgiler öğretmenlerine önemli görevler düşmektedir. Son yıllarda bilim ve teknolojide meydana gelen gelişmeler ve bu gelişmelerin meydana getirdiği bilgi artışı, sosyal bilgiler dersinden ve öğretmenlerinden beklentileri değiştirmiştir. Amerika Birleşik Devletleri'nde bu değişimlere ayak uydurabilmek için sosyal bilgiler öğretmen eğitiminde beş temel eğilim göze çarpmaktadır. Bu çalışmada Parker'ın (2012) ifade ettiği üç eğilime iki eğilim daha ilave edilerek aşağıda belirtilen beş temel eğilimden bahsedilecek ve Türkiye'de sosyal bilgiler öğretmen eğitimine katkıları tartışlacaktır

Bu çalışmanın amacı, Amerika Birleşik Devletleri'nde sosyal bilgiler öğretmeni eğitimi için uygulanan beş temel eğilimi (öğrenciler arasındaki başarı farkının kapatılması, teknolojinin kullanımı, küreselleşme, demokrasi ve eleştirel okuma) tanitmak ve bu eğilimlerin Türkiye'deki sosyal bilgiler öğretmen eğitimi alanına yapabileceği katkıları analiz etmektir. Bu çalışma derleme türünde bir çalışma olup konu ile ilgili erişilebilen çalışmalar incelenmiş, değerlendirmeler yapılarak çeşitli önerilerde bulunulmuştur.

Anahtar Kelimeler: Sosyal bilgiler, öğretmen eğitimi, öğretmen eğitiminde eğilimler.

Main Trends in the Social Studies Teacher Education

* Yrd. Doç. Dr., Uşak Üniversitesi Eğitim Fakültesi 
Uşak Üniversitesi Sosyal Bilimler Dergisi

$2013,6 / 4$

E. KILINÇ

\begin{abstract}
The main aim of the social studies is the promotion of civic competence, which is the knowledge, intellectual processes, and democratic dispositions required of students to be active and engaged participants in public life. Social studies teachers play key role to realize this purpose. Technological developments in recent decades have affected education, as well as social studies. Through technological developments, the expectations of both parents and societies from social studies teachers have been revised. There are five main trends in preservice social studies education programs in the United States to respond these revised expectations.

The purpose of this study is to explain these five main trends (closing achievement gap, technology, globalization, democracy, and critical reading) in the United States; and to analyze these main trends contibution to Turkish preservice social studies education programs. This study examined the related literature; accessed studies were evaluated and some suggestions were made based on the related literature.
\end{abstract}

Key words: Social studies, preservice teacher education, main trends in teacher education programs.

\title{
Giriş
}

Sosyal bilgiler dersi, 20. yüzyılın başında endüstrileşmenin getirdiği sosyal problemlere bir çözüm arayışı olarak Amerika Birleşik Devletlerinde ortaya çıkmış ve bu dersle yetişen yeni neslin topluma karşı sorumluluklarını bilen vatandaşlar olması amaçlanmıştır (Barth, 1977). Sosyal Bilgilerin bir ders olarak ortaya çıkışından itibaren, "Sosyal bilgiler nedir?" sorusuna cevap aranmış ve bu konuda farklı görüşler ortaya atılmıştır (Barr, Barth\&Shermis, 1977; Case \&Abbott, 2008; Wesley, 1937). Bu tanım farklılığına son vermek amaciyla Amerikan Sosyal Bilgiler Ulusal Konseyi (National Council for the Social Studies) kapsamlı bir tanım yapmıştır. Bu tanıma göre sosyal bilgiler: 
Uşak Üniversitesi Sosyal Bilimler Dergisi

$2013,6 / 4$

E. KILINÇ

bireylerin vatandaşlık yeterliliklerini geliştirmek amacıyla, sosyal ve beşeri bilimleri kaynaştıran bir çalışma alanıdır. Okul müfredat programı içerisinde sosyal bilgiler, antropoloji, arkeoloji, ekonomi, coğrafya, tarih, hukuk, felsefe, siyaset bilimi, psikoloji, din ve sosyoloji ile birlikte; beşeri bilimler, matematik ve doğa bilimlerinden uygun içerikler üzerinde, düzenli ve sistematik bir çalışma sağlar (NCSS, 1994, s. 3).

Yukarıdaki tanıma bakılarak sosyal bilgiler dersinin ideal bir öğretim programında önemli bir yeri olduğu söylenebilir. Çünkü sosyal bilgiler dersi öğrencilerin dünyayı (insanları, mekânları, kültürleri, sistemleri ve problemleri) öğrenip değerlendirecekleri bir derstir (Parker, 2012). Sosyal bilgiler dersinde öğrenciler sadece dünyayı tanımakla kalmaz aynı zamanda sistemli bir düşünme becerisi ile onu anlamaya çalışır; eleştirel düşünme ile problemlerine çözüm üretir, bir vatandaş olarak üzerine düşen sorumlulukları yerine getirmeyi öğrenir (Parker, 2012). Bu katkılarıyla birlikte, sosyal bilgiler dersinin doğrudan vatandaşlık eğitimi üzerine odaklanmış bir ders olması ona ayrı bir değer katmaktadır (Öztürk, 2012).

\section{Sosyal Bilgiler Dersinin Amaçları}

Sosyal bilgiler dersinin temel amacı, demokratik bir ülkede vatandaşlık vazifesini yerine getirebilmek için, öğrencilerin sahip olması gereken bilgi, beceri ve davranışlardan meydana gelen vatandaşlık yeterliliklerini arttırıp (NCSS, 1994); onları etkin birer yurttaş ve birey olarak yetiştirmektir (Barth, 1977). Bu nedenle sosyal bilgiler öğretmenlerine büyük bir görev düşmektedir. Son yıllarda bilim ve teknolojide meydana gelen gelişmeler ve bu gelişmelerin meydana getirdiği bilgi artışı, sosyal bilgiler dersinden ve öğretmenlerinden beklentileri değiştirmiştir. Amerika Birleşik Devletleri'nde bu değişimlere ayak uydurabilmek için sosyal bilgiler öğretmen eğitiminde beş temel eğilim göze çarpmaktadır. Bu çalışmada Parker'ın (2012) ifade ettiği üç eğilime iki eğilim (Kılınç, Evans, \& Korkmaz, 2012) daha ilave edilerek aşağıda belirtilen beş temel eğilimden bahsedilecek ve Türkiye'de sosyal bilgiler öğretmen eğitimine katkıları tartışılacaktır. Bu 
Uşak Üniversitesi Sosyal Bilimler Dergisi

$2013,6 / 4$

E. KILINÇ

beklentiler, öğrenciler arasındaki başarı farkının kapatılması, teknolojinin kullanımı, küreselleşme, demokrasi ve eleştirel okuma şeklinde sıralanabilir.

Sosyal bilgiler öğretmenlerinin öncelikle, öğrencilerin kişisel özellikleri ve sosyo-ekonomik düzeylerini önemsemeden, onlara nitelikli eğitim vermesi ve özellikle de öğrenciler arasındaki başarı farkını kapatmaya çalışması gerekir. Bununla birlikte, sosyal bilgiler öğretmenlerinin teknolojiyi etkin bir şekilde kullanması beklentilerden biridir (Kılınç, Evans, \& Korkmaz, 2012). Öğretmenlerin sosyal paylaşım sitelerini, web adreslerini, vb. kullanarak derslerini zenginleştirmesi gerekir. Ayrıca dünyada olup bitenlerden ve bunların günlük yaşamına etkisinden haberdar olan, küresel boyutta kendi yaşıtlarıyla yarışabilecek bireyler yetiştirmesi sosyal bilgiler öğretmenleri için bir gerekliliktir. Dördüncü olarak, demokrasi isteği, belki de bu isteklerden en önemlisidir. Sosyal bilgiler öğretmenlerinin demokratik birer eğitimci olmaları ve öğrencileri de demokrasiyi anlamış, onu hayatına esas kabul etmiş bireyler olarak yetiştirmeleri gerekir. Son olarak, eleştirel okumanın sosyal bilgiler öğretmen eğitiminde kullanılması yeni bir eğilim olarak göze çarpmaktadır. Burada kısaca bahsedilen bu beş farklı eğilim, çalışmada, sırasıyla detaylı bir şekilde açıklanmıştır.

\section{1. Öğrenciler Arasındaki Başarı Farkının Kapatılması}

Amerika Birleşik Devletleri'nde eğitimin devlet tarafından sağlanması ve çocukların halktan alınan vergiler ile eğitim görmesi, 19. yüzyılın ortalarına tarihlenir. Massachusetts Eyaleti Eğitim Komisyonu üyesi olan Horace Mann bu dönemdeki en meşhur reformculardan biri olarak kabul edilir. Horace Mann, eğitimin temel amacının toplumu geliştirmek olduğunu belirtir. Bu nedenle de bir toplumdaki bütün çocuklar, aynı düzeyde eğitim görmelidir (Groen, 2008). Common School Movemevent adı verilen bu reform ne yazık ki sadece beyaz öğrencilerle sınırlı kalmış; Siyahî, Asyalı, Kızılderili, Latin Amerikalı ve diğer etnik gruplar bu reformdan yararlanamamıştır. 1954 yılına gelinceye kadar bu eşitsizlik devam etmiş ve aynı yıl çıkan yasa ile okullarda etnik grupların bir arada ders görmesine imkân tanınmıştır (Gutek, 1995). Ancak bu yasa da öğrencilerin eşit şartlarda eğitim görmesini sağlayamamıştır. Özellikle 
Uşak Üniversitesi Sosyal Bilimler Dergisi

$2013,6 / 4$

E. KILINÇ

Siyahî, Kızılderili ve Latin Amerikalı öğrenciler ile Beyaz öğrenciler arasında fırsat eşitliği yoktur ve başarı açısından bu gruplar arasında büyük farklar bulunmaktadır. Bu fırsat eşitsizliği Amerika Birleşik Devletleri'nde araştırmacılar tarafından irdelenmiş ve bu konuda birçok araştırma yapılmıştır (Anderson, 2007; Howard, 1999; Lewis, 2008; Lubienski, 2002; Shujaa, 1994). Fırsat eşitsizliği üzerine yapılan çalışmalar daha çok Siyahî ve Latin Amerikalı öğrenciler üzerine yoğunlaşmış ve bu öğrencilerin beyaz öğrencilerle arasındaki başarı farkının nedenleri araştırılmıştır. Bu başarı farkının kapatılması amacıyla bir takım uygulamalar yürürlüğe konmuştur. Öğretmen yetiştirmede standartların yükseltilmesi, öğretim programlarında yapılan reformlar, sinıf mevcutlarının azaltılması vb uygulamalar bu uygulamalardan bazılarıdır.

Ülkemize gelince, Türkiye'de eğitimde her bireye fırsat ve imkân eşitliği sağlanması amacı Türkiye Cumhuriyeti Anayasası ve Milli Eğitim Temel Kanunu ile yasal temellere dayandırılmıştır. Bu bağlamda eğitimde genellik ve eşitlik ilkesine göre; her yurttaş, hiçbir ayırım gözetilmeksizin öğrenim ve eğitim hakkına sahiptir. Eğitimde, hiçbir kişiye, aileye veya zümreye ayrıcalık tanınamaz. Fırsat ve olanak eşitliği ilkesine göre ise toplum bireylerine, eğitim görmede fırsat ve olanak eşitliği sağlanır (Sarıer, 2010). Buna ek olarak eğitimde fırsat eşitliliğinin sağlanabilmesi için Yatılı Bölge Ilkögretim Okulu (YIBO) ve Pansiyonlu Ilkögretim Okulu (PIO) uygulaması, taşımalı ilköğretim uygulaması, burs olanaklarının sağlanması, Ilkögretim öğrencilerine ücretsiz ders kitabı temini uygulaması gibi bazı uygulamalar da yapılmaktadır. Ancak bu çalışmalara rağmen ne yazık ki Türkiye'de de eğitim alanında bir fırsat eşitsizliğinden söz edilebilir. Bu eşitsizliği çeşitli gelir grupları arasında, bölgesel ve toplumsal cinsiyet açısından da görmek mümkündür (Şenses, 2007). Eğitimde fırsat eşitsizliğine neden olan etkenler ekonomik, coğrafi, toplumsal, siyasal ve biyolojik etkenler olarak belirtilmiştir (İçer, 1997). Bununla birlikte ailenin gelir seviyesi de kişinin alacağı eğitim düzeyini etkilemektedir. Gelir düzeyi yüksek olan ailelerin çocukları ile gelir düzeyi düşük olan ailelerin çocuklarının eğitim olanaklarından faydalanmaları arasında fark olduğu da ifade edilmiştir (Tezcan, 1994).

Eğitimdeki bu fırsat eşitsizliğinin giderilebilmesi için sosyal bilgiler öğretmenlerine büyük rol düşmektedir. Gerçekten de günümüzde 
Uşak Üniversitesi Sosyal Bilimler Dergisi

$2013,6 / 4$

E. KILINÇ

sosyal bilgiler öğretmenlerinden beklenen, eğitimde fırsat eşitsizliğinin farkında olmaları ve yukarıda bahsedilen olumsuz değişkenlerden etkilenen öğrencileri başarıya ulaştırabilmek için özverili bir şekilde çalışmalarıdır. Eğitimde fırsat eşitsizliğinin farkında olmak, dezavantajlı öğrencileri istenilen vatandaşlık düzeyine çıkarabilme adına önem arz etmektedir. Çünkü öğrencilerin yaşadıkları bölge, ekonomik durum onların ders başarılarını etkilediği gibi vatandaşlık algılarına da etki etmektedir (Bengiç, Şahin, \& Gümüşçü, 2011). Ayrıca anlattıkları derslerle ilgili içerik ve becerileri bilmeleri, farklı özelliklere sahip öğrencilerin de faydalanacakları şekilde farklı eğitim metotlarını kullanmaları, sosyal bilgiler öğretmenlerinin bahsedilen dezavantajlı durumdaki öğrencilerin vatandaşlık becerilerini geliştirmesi adına önemlidir (Parker, 2012). Son olarak, sosyal bilgiler öğretmenlerinin görev aldıkları bölgelerdeki yaşam biçimi, anlayış, kısacası insanlar ile ilgili önyargılarını bir kenara bırakmaları da ayrı bir önemi haizdir.

\section{Teknolojinin Kullanımı}

Bilgi teknolojisindeki hızlı değişmeler 21. yüzyılın bilgi çağı olarak adlanmasına neden olmuş; bilgiye ulaşmada yeni olanaklar sağlamış ve dolayısıyla da bilgiye erişim hızı geçmişe oranla oldukça hızlanmıştır. Bu hızlı değişim, eğitimli insan tanımında da değişikliğe neden olmuştur. Günümüzde eğitimli insan, kendisi ile ilgili gelişmeleri takip edebilen, bunları hayatında uygulayan, sorgulayan, gelişime açık, bilgi ve iletişim teknolojilerini aktif olarak kullanabilen bir kişi olarak tanımlanmaktadır (MEB, 2009). Bu tanıma uygun olarak öğretmenlerden beklenenler de değişmiş ve onlardan teknolojik gelişmeleri takip edebilen ve teknolojiyi kullanarak bilgiye ulaşabilen bireyler yetiştirmeleri beklenilir olmuştur (Akkoyunlu \&Kurbanoğlu, 2003).

Toplum ve teknolojideki değişmelerden dolayı eğitimcilerin ve öğrencilerin rollerinde meydana gelen değişmeler nedeniyle teknolojinin eğitimde kullanılması, birçok araştırmacı tarafından incelenmiştir (Becker, 1994; Cuban, 2001). Özellikle 1970'li yıllarda Amerika Birleşik Devletleri'nde bilgisayarların artık evlere ve okullara girmesi ile birlikte, teknolojinin kullanımı öğrenci merkezli eğitimin altın anahtarı olarak kabul edilmiştir (Fidalgo et al., 2009). Teknolojinin gelişmesiyle birlikte, eğitimin kalitesini 
Uşak Üniversitesi Sosyal Bilimler Dergisi

$2013,6 / 4$

E. KILINÇ

arttırmak ve öğrencilerin derse ilgisini daha çok çekebilmek amacıyla milyonlarca dolar harcanarak okular teknolojinin son ürünleriyle donatılmışlardır. Amerika Birleşik Devletleri'nde son yıllarda yapılan ulusal çaptaki bir araştırmaya göre, öğretmenlerin \%97'sinin sınıflarında en az bir adet olmak üzere bilgisayar bulunduğu belirtilmiştir. Bu yüksek orana rağmen, öğretmenlerin bilgisayarları öğretim sürecinde çok sık kullanmadıkları da ifade edilmiştir (US Department of Education, 2010). Öğretmenlerin teknolojik ürünleri derslerinde çok sık kullanmaması, araştırmacıların dikkatini öğretmen yetiştirme programlarına çekmiştir. Günümüzde öğretmen yetiştiren kurumlardaki öğretim görevlileri, teknolojiyi derslerde nasıl kullanılacağını içeren dersler vermeye, sosyal ağları (facebook, twitter, youtube vb.) derslerinde kullanmaya başlamışlardır (Kılınç, Evans, \& Korkmaz, 2012).

Ülkemizde de bilgisayar kullanımı giderek artmakta ve bilgisayarlar hayatımızın ayrılmaz bir parçası haline gelmektedir. Ülkemizde teknolojinin eğitim sürecinde kullanılması ile ilgili yapılan araştırmaların sonuçları, öğretmenlerin teknolojik imkânlara sahip olmalarına rağmen, derslerinde teknolojiyi pek kullanmadıklarını göstermektedir (Alicigüzel, 2001; Altun, 2002; Keser, 2000). Eğitimde teknolojinin kullanımını arttırmak amacıyla, 2004 yılından itibaren ülkemizde uygulanmaya başlanılan yapılandırmacı yaklaşım ilkelerine uygun olan öğretim programlarında bilişim teknolojilerinin kullanımı önemle vurgulanmıştır (MEB, 2009). Eğitimde Fatih Projesi ile birlikte;

- Bireylerin yaşam boyu öğrenim yaklaşımı ve e-öğrenme yoluyla kendilerini geliştirmeleri için uygun yapıların oluşumu ve e-içeriğin geliştirilmesi,

- Ortaöğretimden mezun olan her öğrencinin temel bilgi ve iletişim teknolojileri kullanım yetkinliklerine sahip olması,

- İnternetin etkin kullanımı ile her üç kişiden birisinin e-eğitim hizmetlerinden faydalanmasi,

- Herkese bilgi ve iletişim teknolojilerini öğrenme ve kullanma firsatının sunulması,

- Her iki kişiden birinin internet kullanıcısı olması,

- İnternet, toplumun tüm kesimleri için güvenilir bir ortam haline getirilmesi 
Uşak Üniversitesi Sosyal Bilimler Dergisi

$2013,6 / 4$

E. KILINÇ

hedeflenmiştir (MEB, 2009).

Yukarıda belirtilen hedeflerin gerçekleştirilmesinde şüphesiz en büyük görev öğretmenlere düşmektedir. Teknolojik gelişmelerle birlikte, teknolojinin eğitimin kalitesi ve öğrencilerin derse olan ilgisini arttırmada bir araç olarak kullanılabilmesi, sosyal bilgiler öğretmeni adaylarına bu konuda eğitim verilmesi ihtiyacını ortaya çıkarmaktadır. Sosyal bilgiler öğretmenlerin teknolojik aletleri derslerinde yeterli ve etkili bir şekilde kullanamaması, öğretmenin etkinliğinin azalmasına neden olmakta ve öğrencilerin sosyal bilgiler dersine olan ilgisini azaltmaktadır (Karal \&Berigel, 2006). Bu nedenle, eğitim fakültelerinde teknoloji kullanımı ile ilgili ders sayısı arttırılarak, sosyal bilgiler derslerinde teknolojinin nasıl kullanılacağı uygulamalı olarak anlatılmalı, sosyal bilgiler öğretmeni adaylarının teknolojiyi eğitim ortamlarında etkin bir şekilde kullanabilecek donanımda mezun olmasını sağlanmalıdır. Mevcut sosyal bilgiler öğretmenlerinin teknoloji destekli eğitim alanındaki eksiklikleri de bu konularda hizmet içi seminerler verilerek giderilmelidir.

\section{Küreselleşme}

Küreselleşme günlük hayatımızda sıklıkla duyduğumuz, başka bir tabirle kullanılması moda bir kavramdır. Küreselleşme, dünyanın herhangi bir yerinde meydana gelen sosyal, siyasal ya da ekonomik olayın yakın veya uzaktaki başka yerlerde de kendini hissettirmesi olarak tanımlanabilir (Oktay, 2010). Bazılarına göre küreselleşme mutluluk getiren bir olgu, bazılarına göre ise de mutsuzluğun kaynağı olarak anlaşılmaktadır (Bauman, 1998). Sosyolog Anthony Giddens (1991) küreselleşmeyi, günümüz dünyasının daha önceki dönemlerdeki dünyadan farklı bir dünya olduğunu söyleyerek açıklar. Gerçekten de günümüzde sosyal hayatımızın büyük bir kısmı küresel olaylardan etkilenmekte; bununla birlikte millî kültürler, millî ekonomiler ve millî sınırlar giderek zayıflamaktadır (Hirst \& Thompson, 1999). Teknolojide, bilimlerde ve ekonomideki küresel gelişmeler, toplumsal değerlerde, kurumların yapısında, devlet yapılarında ve millî vatandaşlık anlayışında bazı değişikliklere neden olmaktadır (Sassen, 1996). 
Uşak Üniversitesi Sosyal Bilimler Dergisi

$2013,6 / 4$

E. KILINÇ

Küreselleşmenin günümüz dünyasını olumlu mu yoksa olumsuz mu etkilediği tartışmasını bir tarafa bırakıp, bu değişimin kaçınılmaz olduğunun farkına varılması gerekir. Günümüzde, Türkiye Cumhuriyeti Devleti de bu değişimden ekonomik, bilimsel, teknolojik ve kültürel olarak etkilenmektedir. Tam bu noktada bir soru ortaya çıkmaktadır. Acaba bizler öğrencilerimizi, ahlaki, politik ve ideolojik olarak geleceğin eşit, aktif, enerjik dünyasına ayak uyduracak bireyler olarak hazırlıyor muyuz (Rapoport, 2009a)?

Küresel vatandaşlık eğitimi, son 20 yılda eğitim alanında giderek önem kazanan bir konudur. Akademik konferans ve dergilerde gittikçe yaygınlık kazanmaktadır. Rapoport (2009a) küresel vatandaşlık eğitiminin evrensel bir tanımı olmayıp zaman zaman uluslararası eğitim, küresel eğitim, kültürlerarası eğitim, barıș eğitimi ve insan hakları eğitimi olarak da kullanıldığını ifade eder. Rapoport aynı zamanda bazı küresel vatandaş tanımlarına da makalesinde yer vermiştir. NelNoddings'e (2005) göre küresel vatandaş, dünyanın herhangi bir yerinde yaşayabilen ve çalışabilen, küresel yaşama ayak uydurabilen bireydir. Bir başka tanımda ise küresel vatandaş, bütün dünyada meydana gelen önemli güncel meseleleri bilen ve ilgilenen birey olarak tanımlanır (Dunn, 2002). Kan (2009) ise küresel vatandaşı "hukuksal anlamda bir dünyaya ait olma gibi bir kimliğe sahip olmamakla birlikte yaşam tarzı ve hayat anlayışı olarak küresel ölçekte bilgi, beceri ve anlayışa sahip" (s. 896) birey olarak ifade eder. Gerçekten de küresel vatandaşlık eğitimi 21. yüzyıl için ihtiyaç duyulan bir gelişmedir. Ancak, küresel vatandaşlık eğitimine karşı bazı eleştiriler gelmekte ve okullarda uygulanmasında bir takım zorluklarla karşılaşılmaktadır.

21. yüzyılın en moda kavramlarından bir tanesi olan küreselleşme, olumlu ve olumsuz olmak üzere sosyal hayata etki etmektedir. Bu nedenle de günümüz insanının küreselleşme ile ortaya çıkan yeniliklere yabancı kalmaması, bu yeniliklere göre hayatını yeniden düzenlemesi gerekmektedir. Dünyanın ekonomik, sosyal ve teknolojik olarak nasıl işlediğini anlayan; küreselleşen dünyanın ve bu dünyada kendi yerinin farkında olan; farklılıklara saygı duyup değer veren; sosyal adaletsizliklerle mücadele eden; kendi toplumunu ve bütün dünyayı ilgilendiren toplumsal projelere katkıda bulunan bireyleri (Kan, 2009; Oxfam, 2011) yetiştirmede eğitime, özellikle de sosyal bilgiler eğitimine büyük görevler düşmektedir. 
Uşak Üniversitesi Sosyal Bilimler Dergisi

$2013,6 / 4$

E. KILINÇ

Küresel vatandaşlık eğitiminin okullarda uygulanmasındaki en büyük engellerden bir tanesi sosyal bilgiler dersi öğretmenlerinin bu kavrama yabancı olmasıdır. Amerika Birleşik Devletleri'nde küresel vatandaşlık eğitiminin çok fazla işlenmemesinin temel nedeni de öğretmenlerin bu kavramla ilgili farkındalıklılarının düşük olmasıdır (Rapoport, 2009b). İngiltere'de küresel vatandaşlık eğitiminin önemine inanan 700 öğretmen üzerinde yapılan bir çalışmada, sadece bir kaçının küresel vatandaşlık eğitimini vermede kendine güvendiği sonucu ortaya çıkmıştır (Rapoport, 2009a).

Okullarda küresel vatandaşlık eğitiminin uygulanmasındaki bir diğer engel de daha önce de belirtildiği üzere bir tanım birliğinin bulunmaması ve literatürdeki uyuşmazlıktır (Rapoport, 2009b). Bu alanda birçok tanımın bulunması, araştırmacılar ve eğitimciler arasında bir uzlaşma olmaması, öğretmenlerin bu konuyu öğretmek noktasında kendilerine güvenmemelerine neden olmaktadır.

$\mathrm{Bu}$ konudaki bir diğer büyük problem ise sosyal bilgiler müfredatında öğretmenlere yol gösterecek yeterli oranda bilgi bulunmamasıdır (Enger \& Hunt, 2004). Rapoport'un yaptığı araştırma (2009b) küreselleşme kavramının, Amerika Birleşik Devletleri'nde sadece 15 eyaletin sosyal bilgiler standartlarında yer aldığını; buna karşılık, küresel vatandaş kavramının hiçbir eyaletin sosyal bilgiler standartlarında yer almadığını göstermektedir.

Küresel vatandaşlık eğitiminin başarıya ulaşabilmesi için öncelikle araştırmacılar arasında bir tanım birliğine ulaşılması ve literatürdeki uyuşmazlıklar giderilmelidir. Kavram karmaşası aşıldıktan sonra da sosyal bilgiler öğretmeni yetiştiren eğitim fakültelerinde bu adla bir ders verilmeli; Küresel vatandaşlık kavramının önemi diğer derslerde de öğretmen adaylarına benimsetilmelidir. Eğitimden hedeflenenin sadece ulusal sınırlar içerisinde başarılı olabilecek insanlar değil de uluslararası arenada kendini gösterecek, farklı kültür ve coğrafyalarda başarılı olabilecek insan olması gerektiği kabul edilmelidir. Sosyal bilgiler öğretmenlerine kendi kültürleri yanında dünyada yaygın değişik kültürler de öğretilmeli ve sosyal bilgiler öğretmen eğitimi programlarında dünya tarihi, dünya coğrafyası ve dünya kültürleri gibi dersler yer almalıdır. Aynı zamanda sosyal bilgiler öğretim 
Uşak Üniversitesi Sosyal Bilimler Dergisi

$2013,6 / 4$

E. KILINÇ

programlarında da küreselleşme ve hayatımıza etkileri konuları arttırılmalıdır.

\section{Demokrasi}

John Dewey (1916) eğitim klasikleri arasındaki kitabı Demokrasi ve Eğ̊itim adlı eserinde insanoğlunun asla eğitimsiz bırakılmaması gerektiğini çünkü insanoğlunun kendi başına toy ve olgunlaşmamış olduğunu ifade eder. Eğer insanoğlu eğitimsiz bırakılırsa fiziksel varlığını devam ettirebilmesi için gerekli olan becerileri elde edemez. Günümüzdeki en önemli becerilerden birisi de demokratik yaşam becerisidir. İnsanoğluna bu becerileri kazandıracak müessese ise okuldur.

Günümüzde üzerinde en çok konuşulan-tartışılan kavramlardan biri olan demokrasi, insanları 'vatandaş' kavramı altında bir araya toplayan idare biçimi olarak tanımlanır (Dietz, 1992). Diğer bir ifade ile demokrasi, bir insan grubunun sosyal içerikli bir buluş, değerler ve kurallar bütünlüğü olan (Yılman, 1992) bir kavramdır. Demokrasi sadece bir hükümet biçimi değil, aynı zamanda bir yaşam felsefesi ve yaşayış biçimi (Ertürk, 1981) olarak da değerlendirilmektedir.

Dietz'in (1992) tanımında belirttiği üzere, eğer demokrasi kavramını içinde yaşadığımız toplumu bir arada tutan bir unsur olarak değerlendirirsek, insanları bu anlayışla eğitmemiz gerekecektir. Demokratik vatandaşlar olmadan demokrasinin olmayacağı önemli bir gerçektir (Parker, 2003). Gerçekten de demokratik hükümetleri meydana getiren ve devamını sağlayanlar halktır. Demokrasinin temel ilkeleri olan bağımsızlık, eşitlik, adalet gibi kavramları benimsemiş bu vatandaşlar bu temel bilgi ve becerileri doğuştan kazanmazlar, ancak eğitimle kazanırlar (Parker, 2003). Yukarıda da belirtildiği üzere bu bilgi ve becerilerin kazandırılacağı temel müessese okuldur (Dewey, 1916).

Demokrasi öğrenilebilecek bir yaşam tarzı ise de, sadece okuldaki formal eğitimle kazanılabilecek bir değerler sistemi değildir. Dolayısıyla, sadece okullarda demokrasi ve insan haklarına ilişkin dersler koymak suretiyle yeni nesillere aktarılabilecek bir şey değildir (Okutan, 2010).Ancak, sosyal bilgiler öğretmenleri kendilerini demokrasi eğitmenleri olarak gördüğünde, demokrasinin temel unsurlarını kendi derslerinde uygulamalı 
Uşak Üniversitesi Sosyal Bilimler Dergisi

$2013,6 / 4$

E. KILINÇ

olarak gösterdiklerinde (Parker, 2003), okul, öğrencinin demokratik yaşamı yasayarak öğrendiği ortamlar haline getirildiğinde, öğrencilerin okullarda demokratik yaşam kültürünü öğrenecekleri söylenebilir (Okutan, 2010). Öte taraftan, sosyal bilgiler öğretmenleri sadece demokrasinin tanımını öğrencilere ezberletip, demokrasi ile ilgili kavramları öğrencilere öğretmesi demokratik vatandaşlar yetiştirme adına bir önem ifade etmemektedir. Bu nedenle, sosyal bilgiler öğretmenleri, kendi dersi ile ilgili konularda öğrencilerin fikirlerini ifade etmesine olanak sağlamalı, kendileri ile ilgili kararlarda söz hakkı tanımalı ve demokrasiyi sınıfında yaşatmalıdır.

\section{Eleştirel Okuma ve Sosyal Bilgiler Dersi}

Öğrencilerin sosyal bilgiler dersinde gerekli bilgileri elde etmesi için okuma becerisi oldukça önemlidir çünkü sosyal bilgiler dersinde başvurulan içeriğin \%85-\%90'1 ders kitapları ve kaynak kitaplardan karşılanmaktadır (Myers \& Savage, 2005). Amerika Birleşik Devletleri'nde yapılan bir araştırmada, Freeland (1978) üç farklı sosyal bilgiler ders kitabını incelemiş ve bu ders kitaplarında kullanılan kelimelerin \%90'ının soyut sosyal bilgiler kavramlarında oluştuğu sonucuna ulaşmıştır. Bu araştırma okuma becerisinin sosyal bilgiler dersinde ne kadar önemli olduğunu göstermektedir. Bununla birlikte, teknolojik gelişmeler öğrencilerin dünyadaki politik, ekonomik, kültürel ve sosyal gelişmelere daha hızlı ve kolay ulaşmasını sağlamıştır. Ancak mevcut teknolojinin bilgiye hızlı ve kolay ulaşmasını sağlaması insanları gereksiz, yanlış, sübjektif ve eksik bilgiyle karşı karşıya kalmalarına da yol açmıştır (Özensoy, 2011). Bu yüzden öğrencilerin okudukları bilgileri hemen kabul etmeyip, sorgulayarak ve eleştirel bir bakış açısıyla yaklaşarak doğruluğunu araştırması gerekir. Bu süreçte eleştirel okuma karşımıza çıkmaktadır (Özensoy, 2011). Gerçekten de okuma, sadece kelimelerle sinirlı olmayıp, okuyucunun anlam kurabildiği görsel ve yazılı araçları kullanıp yeni bir senteze ulaşma durumudur. Eleştirel okuma okuyucunun metinden anlam çıarması (Marschall, 2012), soru sorarak, hipotezler üreterek, kanıtlar araştırarak, öne sürülen varsayımları değerlendirerek metinde verilen bilgilerin ötesine ulaşması (Langer, 1990) olarak tanımlanır. 
Uşak Üniversitesi Sosyal Bilimler Dergisi

$2013,6 / 4$

E. KILINÇ

\section{Neden Eleştirel Okuma}

Sosyal bilgiler dersinin temel amacı demokratik bir ülkede vatandaşlık vazifesini yerine getirebilmek için öğrencilerin sahip olması gereken bilgi, beceri ve davranışlardan meydana gelen vatandaşlik yeterliliklerini arttırıp (NCSS, 1994) onlari etkin birer yurttaş ve birey olarak yetiştirmektir (Barth, 1977). Okuduğunu anlama, değerlendirme, yazılı ve görsel bilgileri kullanma demokratik vatandaşlar yetiştirmede temel unsurlardandır. Güçlü demokrasiler sadece okuduklarını anlayan bireylerle değil aynı zamanda okuduklarını sorgulayan, eleştirel bir gözle yazılanları inceleyen bireylerle ayakta kalır (O'Quinn, 2006). Gerçekten de demokratik toplumların ayakta kalabilmeleri için bireylerin sivil özgürlükleri korumak ve devam ettirmek adına birlikte çalışmaları ve ortak problemlere ve endişelerine çözüm üretmeleri gerekir. Bu süreçte de eleştirel okuma önemli bir rol sahibidir (Reidel\&Draper, 2011).

Eleştirel okuma demokratik vatandaşlar yetiştirmede yukarıda belirtildiği kadar önemli olsa da sosyal bilgiler ya da vatandaşlık eğitimi derslerinde yeterli şekilde kullanılmamaktadır (Levstik, 2008; Parker, 2008). Ne yazık ki bireysel bazı çalışmalar olsa da (Dönmez \& Yazıcı, 2006, Özensoy, 2011; Yazıcı \&Yeşilbursa, 2007) ülkemizde de aynı eksiklik söz konusudur. Akademik çalışma alanında olduğu gibi uygulama alanında da eksiklikler göze çarpmaktadır. Bir çok branş öğretmeni okuma eğitimini kendi sorumlulukları içerisinde görmemekte ve okuma becerilerini kendi derslerine dahil etmemektedir (Hall\&Piazza, 2005). Sosyal bilgiler dersi için bu problemin çözümü adına, eğitim fakültelerinde sosyal bilgiler alanı okumaları ile ilgili dersler açılarak, öğretmen adayları eleştirel okuma konusunda eğitilmelidir. Bu beceri ile yetişen öğretmenler de öğrencilere eleştirel okuma becerisi kazandırarak öğrencilere karşılaştıkları bilgileri eleştirel bir gözle incelemelerini sağlamalıdır.

\section{Sonuç}

Sonuç olarak, bu çalışmada bahsedilen beş eğilim sosyal bilgiler öğretmen eğitiminde dikkate alınmalıdır. Sosyal bilgiler öğretmenlerini yetiştirirken, bu öğretmenlerin öğrencilere 21. yüzyılın en önemli 
Uşak Üniversitesi Sosyal Bilimler Dergisi

$2013,6 / 4$

E. KILINÇ

unsurlarından biri olan bilgiye nasıl ulaşacaklarını, bilgiyi yorumlayarak nasıl yeni bilgiler elde edeceklerini öğreteceklerini dikkate almak zorundayız. İçerisinde bulunduğumuz teknoloji/bilgi çağında, muasır medeniyetler seviyesine ulaşmak için teknolojiyi bilen ve aktif kullanan sosyal bilgiler öğretmenlerine ihtiyacımız olduğu bir gerçektir. Bununla birlikte, öğrencilere model olma anlamında, küresel gelişmeler hakkında bilgi sahibi ve bu gelişmelerin yaşantımız üzerindeki etkilerinin farkında olan sosyal bilgiler öğretmenleri, gelecek nesilleri, küresel boyutta bilgi sahibi ve dünyanın her coğrafyasında iş bulabilecek nitelikte ve kalitede yetiştirecektir. Ülkemizdeki demokrasinin devamı adına, demokrasiyi yaşayarak öğrenen, farklı fikirlere saygılı bireyler de bu öğretmenler eli ile yetişecektir. Son olarak, her duyduğuna inanmayan, ulaştığı bilgileri eleştirel bir gözle değerlendirerek doğru bilgiye ulaşmaya çalışan bireyler yetiştirmede de sosyal bilgiler öğretmenlerinin etkisi göz önünde bulundurulmalıdır. 
Uşak Üniversitesi Sosyal Bilimler Dergisi

$2013,6 / 4$

E. KILINÇ

\section{Kaynakça}

Akkoyunlu, B. ve Kurbanoglu, S. (2003). Öğretmen adaylarının bilgi okuryazarlığ ve bilgisayar öz-yeterlik algıları üzerine bir çalışma. Hacettepe Üniversitesi Egĭtim Fakültesi Dergisi. 24, 110.

Alıcıgüzel, İ. (2001). Çă̆daş okulda eğitim ve öğretim. İstanbul: Sistem Yayıncilik.

Altun, S. A. (2002). Okul yöneticilerinin teknolojiye karş1 tutumlarının incelenmesi. Çă̆daş Ĕ̆itim, 286, 8-14.

Anderson, J. (2007). The historical context for understanding

the test score gap. The National Journal of Urban
Education \& Practice,
$1,1-21$.

Barr, R. D., Barth, J. L., \& Shermis, S. S. (1977). Defining the social studies. Arlington, VA: National Council for the Social Studies.

Barth, J. L. (1977). Advanced social studies education. Washington, DC: University Press of America.

Bauman, Z. (1998). Globalization: The human consequences. New York: Columbia University Press.

Becker, J. M. (1969). Organizing the social studies program. In D. M. Fraser (Ed.), Social studies curriculum development:

Prospect and problems (pp. 65-99). Washington, D. C.: National

Council for the Social Studies.

Case, R., \& Abbott, M. (2008). Purposeful teaching in secondary social studies. In R. Case \& P. Clark (Eds.) The anthology of social 15-24). Vancouver: Pacific Educational Press.

Cuban, L. (2001). Oversold and underused: Computers in the classroom. Cambridge, MA: Harvard University Press.

Dewey, J. (1916). School and society: An introduction to the philosophy of education. Michigan; Macmillan.

Dietz, M. G. (1992). Feminizm and theorşes of citizenship. In C. Mouffle(Ed.), Dimensions of radical democracy: Pluralism, citizenship, community (pp. 63-85). London: Verso. 
Uşak Üniversitesi Sosyal Bilimler Dergisi

$2013,6 / 4$

E. KILINÇ

Dönmez, C. \& Yazıc1, K. (2006). Sosyal bilgilerde öğrencilerin okuduğunu anlama becerilerinin geliştirilmesinde metin yapısına bağlı olarak kullanılabilecek strateji ve teknikler.

Manas Üniversitesi, Sosyal Bilimler Dergisi, 16, 138-154.

Dunn, R.R. (2002). Growing good citizens with a worldcentered curriculum. Educational Leadership, 60(2), 10-13.

Engler, J. M., \& Hunt, Jr. J. B. (2004). Preparing our students for work and citizenship in the Global Age. Phi Delta Kappan, 86(3), 197-199.

Ertürk, S. (1981). Diktacı tutum ve demokrasi. Ankara, Yelkentepe Yayınları.

Fidalgo-Neto, A.A., Tornaghi, A.J.C., Meirelles, R.M.S., Berçot, F.F., Xavier, L.L., Castro, M.F.A., \& Alves, L.A. (2009). The use of computers in Brazilian primary and secondary schools.

Computers \& Education, 53, 677-685.

Freeland, K. (1978). Technical vocabulary and comprehension of social studies material, Indiana Social Studies Quarterly, 30, 15-19.

Giddens, A. (1991). The consequences of modernity. Stanford: Stanford University Press.

Groen, M. M. (2008). The Whig Party and the rise of Common Schools, 1837-1854 party and policy reexamined. American Educational History Journal, 35(2), 251-260.

Gutek, G.L. (1995). A history of the Western educational experience. Second edition. Illionis: Waveland Press.

Hall, L., and S. Piazza. (2008). Critically reading texts: What students do and how teachers can help. The Reading Teacher 62 (1): 3241.

Hirst, P. Q., \& Thompson, G. (1999). Globalization in question. Malden, MA: Blackwell Publishers Inc.

Howard, G. (1999). We can't teach what we don't know. New York: Teachers College Press.

İçer, M. M. (1997). Türkiye'de eğitim sisteminin genel amaçları ve temel eğitim ilkelerinin değerlendirilmesi. Yayınlanmamıs, Yüksek 
Uşak Üniversitesi Sosyal Bilimler Dergisi

$2013,6 / 4$

E. KILINÇ

lisans Tezi, Inönü Üniversitesi Sosyal Bilimler Enstitüsü, Malatya.

Kan, C. (2009). Değişen değerler ve küresel vatandaşlık eğitimi. Kastamonu Ĕ̆itim Dergisi, 17(3), 895-904.

Karal, H., Berigel, M. (2006). Eğitim Fakültelerinin öğretmenlerin teknolojiyi eğitimde etkin olarak kullanabilme yeterlilikleri üzerine etkileri ve çözüm önerileri. Çukurova Üniversitesi Ĕ̆itim Fakültesi Dergisi, 3(32), 60-67.

Keser, H. (2000). Yönetici adaylarının teknolojiye yönelik tutumları. IV. Fen Bilimleri Eğitimi Kongresi (s. 696-700). Ankara: MEB Öğretmen Yetiştirme ve Eğitimi Genel Müdürlüğü.

Kılınç, E., Evans, R., \& Korkmaz, U. (2012). Aligning Facebook and Twitter with social studies curriculum. In P. Resta (Ed.), Proceedings of Society for Information Technology \& Teacher Education International Conference 2012 (pp. 517-521).

Chesapeake, VA: AACE.

Langer, J. A. (1995). Envisioning literature: Literary understanding and literature instruction. New York, NY: Teachers College Press.

Levstick, L. (2008). What happens in social studies classrooms?

Research on K-12 social studies. In L. Levstick \& C. Tyson (Eds.), Handbook of research in social studies education, (pp.5064). New York: Routledge.

Lewis, C., James, M., Hancock, S., \& Hill-Jackson, V. (2008). Framing African American students' success and failure in urban settings: A typology for change. Urban Education, 43(2), 127153.

Lubienski, S. T. (2002). A closer look at Black-White mathematics gap: Intersections of race and SES in NAEP achievement and instructional practices data. The Journal of Negro Education, 71(4), 269-287.

Marschall, S. (2012). A conceptual framework for teaching critical reading to adult college students. Adult Learning, 23(2), 6368.

Milli Ĕ̆itim Bakanlığı. (2009). Hayat boyu öğrenme strateji belgesi. Ankara. 
Uşak Üniversitesi Sosyal Bilimler Dergisi

$2013,6 / 4$

E. KILINÇ

Myers, M. P. \& Savage, T. (2005). Enhancing Student

Comprehension of Social Studies Material. The Social Studies 96(1), 18-23.

National Council for the Social Studies. (1994). Curriculum standards for social studies: Expectations of excellence. Washington, DC: National Council for the Social Studies.

Noddings, N. (2005). Global citizenship: Promises and problems. In N. Noddings (Ed.), Educating citizens for global awareness (pp. 1-21). New York: Teachers College Press.

O'Quinn, E. 2006. Critical literacy in democratic education:

Responding to sociopolitical tensions in U.S. schools. Journal of Adolescent and Adult Literacy 49 (4): 260-267.

Oktay, A. (2010). 21. Yüzyılda yeni eğilimler ve eğitim. İçinde O. Oğuz, A. Oktay, \& H. Ayhan (Eds.), 21. Yüzyılda eğitim ve Türk eğitim sistemi, (s. 1-20), Ankara: PegemA.

Okutan, M. (2010). Türk eğitim sistemi'nde demokrasi eğitimi. Uluslararası İnsan Bilimleri Dergisi, 7(1), 938-946.

Oxfam. (2012, September 5). Global citizenship education. Retrieved f rom

http://www.oxfam.org.uk/education/gc/files/education_for_global_c itizenship_a_guide_for_schods_pdf

Özensoy, A. U. (2011). Eleştirel okumaya göre düzenlenmiş sosyal bilgiler dersinin eleştirel düşünme becerisine etkisi. Mersin Üniversitesi Eğitim Fakültesi Dergisi 7(2),13-25.

Öztürk, C. (2012). Sosyal bilgiler: Toplumsal yaşama disiplinlerarası bir bakış. İçinde C. Öztürk (Ed.), Sosyal bilgiler öğretimi, (s.233). Ankara:PegamA.

Parker, W. C. (2003). Teaching democracy: Unity and diversity in public life. New York, NY: Teachers College Press.

Parker,W. (2008). Knowing and doing in democratic citizenship. In L. Levstick \& C. Tyson (Eds.), Handbook of research in social studies education, (pp.65-81). New York: Routledge.

Parker, W. (2012). Social studies in elementary education. Boston: Pearson. 
Uşak Üniversitesi Sosyal Bilimler Dergisi

$2013,6 / 4$

E. KILINÇ

Rapoport, A (2009b). Lonely business or mutual concern: The role of comparative education in the cosmopolitan citizenship debates. Current Issues in Comparative Education, 12(1), 23-32.

Rapoport, A. (2009a). A forgotten concept: Global citizenship education and state social studies standards. The Journal of Social Studies Research, 33(1), 91-112.

Reidel, M., \& Draper, C. A. (2011). Reading for democracy: Preparing middle-grades social studies teachers to teach critical literacy. The Social Studies, 102, 124-131.

Sarıer, Y. (2010). Ortaöğretime Giriş Sınavları (OKS-SBS) ve PISA sonuçları 1şınğında eğitimde fırsat eşitliğinin

değerlendirilmesi. Ahi Evran Üniversitesi Egĭtim Fakültesi Dergisi, 11(3), 107-129.

Sassen, S. (1996). Losing control?: Sovereignity in an age of globalization. New York: Columbia University Press.

Shujaa, M. (1994). Too much schooling, too little education: A paradox of Black life in White societies. Trenton, NJ: Africa World Press.

Şenses, F. (2007). Uluslar arası Gelişmeler Işı̆̆ında Türkiye Yüksek öğretim Sistemi: Temel Eğilimler, Sorunlar, Çelişkiler ve Öneriler. ERC Working Papers in Economics N. 07,05.

Tezcan, M.(1994). Egìtim sosyolojisi. Zirve Ofset, Ankara.

U.S. Department of education. (2010). Teachers' use of educational technology in U.S. public schools: 2009. Washington DC:

National Center for Educational Statistics.

Wesley, E. B. (1937). Teaching the social studies. Boston, MA: D. C. Health.

Yazıcı, K. ve Yeşilbursa, C, C. (2007). Sosyal bilgiler derslerinde yazılı materyallerin öğrencilerin okuma seviyelerine uygunluğunun belirlenmesinde kullanılan ölçme araçları. Türkiye Sosyal Araştırmalar Dergisi, 1, 83-99.

Yılman, M. (1992). Demokrasimizin kültürel temelleri. İzmir, Reform Yayınları. 